\title{
Path analysis between yield components of wheat under different top-dressing nitrogen management
}

\author{
Alan Junior de Pelegrin ${ }^{1}$, Maicon Nardino ${ }^{2 *}$, Mauricio Ferrari ${ }^{3}$, Ivan Ricardo Carvalho ${ }^{4}$, Vinicius Jardel \\ Szareski ${ }^{3}$, Antonio Costa de Oliveira ${ }^{1}$, Velci Queiróz de Souza ${ }^{5}$ and Luciano Carlos da Maia ${ }^{1}$ \\ ${ }^{1}$ Universidade Federal de Pelotas, Capão do Leão, RS, Brasil. \\ 2 Universidade Federal de Viçosa, Viçosa, MG, Brasil. \\ ${ }^{3}$ SLC Agrícola, Porto Alegre, RS, Brasil. \\ ${ }^{4}$ Universidade Regional do Noroeste do Estado do Rio Grande do \\ Sul, ljuí, RS, Brasil. \\ ${ }^{5}$ Universidade Federal do Pampa, São Gabriel, RS, Brasil. \\ *Author for correspondence: nardino@ufv.br
}

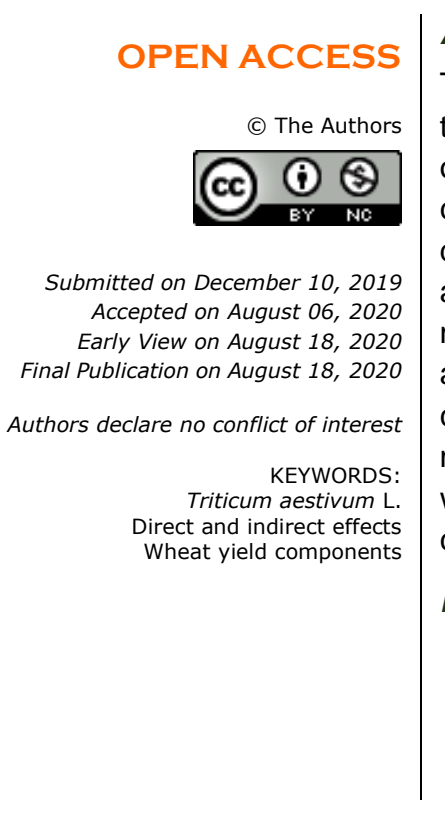

\section{ABSTRACT}

There is little research that addresses associations between the yield of wheat grains and their components in different managements of nitrogen fertilization top dressing. The objective this work linear estimate associations cause and effect between production components and the yield grains in the difference scenarios nitrogen $(\mathrm{N})$ management in top dressing wheat two crops 2012 and 2013. Experimental design was randomized blocks, arranged scheme split-split-plot, with three genotypes $\times$ two crops $\times$ two source $\mathrm{N} \times$ four management in top dressing. $(3 \times 2 \times 2 \times 4)$, in the three replications. Linear correlation and path analysis were estimate in the different $\mathrm{N}$ management. Management $\mathrm{N}$ in top dressing change magnitude linear associations in the wheat. Number fertile tillers independent management in top dressing have positive relation of cause and effect with yield grains in the wheat. Mass grains spike principal in the management II, III and IV prove positive relation cause and effect with yield grains in the wheat.

\section{Highlighted Conclusions}

1. Nitrogen management top dressing changes magnitude of linear association.

2. Number fertile tillers has positive cause relation with yield grains in wheat.

3. Mass of grains of main spike can have positive-causal relation with wheat yield grains depending on the top-dressing management.

\section{INTRODUCTION}

Wheat is the second most produced cereal in the world and its importance is justified by the high demand for derivatives, especially for the production of flour and animal feed (Pinnow et al. 2013). The southern region of Brazil is responsible for more than $90 \%$ of national production. The states Paraná and Rio Grande do Sul, in Brazil, are responsible for the largest contribution, with an estimated production of 4.5 million tons (Conab 2019).

Success in wheat grains yield is related to the cultivar's genetics, climatic conditions and management during the development cycle. Nitrogen $(\mathrm{N})$ is the nutrient required in high doses, has a strong influence on productivity and wheat production components (Kutman et al. 2011, Benin et al. 2012, Xu 2012).

Total mineral nitrogen applied to wheat, around 40 to $60 \%$ is assimilated by the plant and used by the metabolism to perform metabolic functions and maximize productive performance (Barraclough et al. 2010, Górny et al. 2011). The management of $N$ in top dressing can change the magnitude of the relationships between traits and direction of indirect selection. Paterniani and Campos (2005) reported that when using the correlation between characters, the efficiency of selecting a character is significantly increased. In genetic improvement, the study of associations between characters is relevant, because based on these associations it is possible to obtain an indication of how the researcher should operate in the indirect selection of individuals.

The associations indicate the possibility of obtaining gains by selection in correlated characters, since the characters of low heritability or of difficult measurement, can be efficiently selected when the selection is based on characters of greater heritability and which present high magnitudes of correlation (Cruz and Regazzi 1997). 
Pearson's linear correlation analysis is a tool used to define the trend of linear associations between character pairs. However, its direct interpretation can lead to errors in the interpretations, making the unfolding of linear relationships into cause and effect associations crucial path analysis (Wright 1921), which makes it possible to determine the direct and indirect effects of explanatory variables on the dependent variable (Cruz et al. 2014).

Silva et al. (2005), Vieira et al. (2007), Gondim et al. (2008) and Kavalco et al. (2014) conducted research with the objective of understanding the linear and cause and effect associations between the components of wheat crop production. However, there are few studies addressing the behavior of associations between wheat grain yield and its components under different nitrogen fertilization managements. Based on this rationale, the present research conducted in two crops had the aim to estimate linear associations, cause and effect between in the production components and yield grains considered different management $\mathrm{N}$ in the top-dressing wheat.

\section{MATERIAL AND METHODS}

Experimental material. Experiment was conducted in two agricultural crops 2012 and 2013 respectively, in Frederico Westphalen, RS, Brazil, located at $27^{\circ} 23^{\prime} 48.17^{\prime \prime} \mathrm{S}$ and $53^{\circ} 25^{\prime} 34.82^{\prime \prime}$ WGr. and altitude of 460 meters. The soil in the area in which the experiment was conducted is classified as a Latossolo Vermelho Distrófico (Santos et al. 2006) and the climate is characterized by Köppen as subtropical Cfa (Alvares et al. 2013).

Experimental design. Experimental design was randomized blocks, arranged scheme split-plot, with three genotypes $\times$ two crops $\times$ two source $\mathrm{N} \times$ four management in top dressing. $(3 \times 2 \times 2 \times 4)$, in the three replications. The experimental units were composed of 12 lines with a spacing of $0.17 \mathrm{~m}$ between lines and $3.5 \mathrm{~m}$ long, totaling $7.14 \mathrm{~m}^{2}$. For the evaluations, the eight central lines were collected and $0.5 \mathrm{~m}$ at the ends were eliminated.

The utilized genotypes were: Fundacep 52, TBIO Mestre and TBIO Itaipu. The nitrogen sources used were: Urea (45\% nitrogen) and Ammonium nitrate (33.5\% nitrogen). The nitrogen managements were: I: absence of nitrogen in top dressing, II: $100 \%$ in the tillering, III: $50 \%$ in the tillering and $50 \%$ in the booting and IV: $33.3 \%$ in the tillering, $33.3 \%$ in the booting and $33.3 \%$ at flowering.

Cultural management. Cultural management was carried out in accordance with technical recommendations for the cultivation of wheat. For the control of pests and diseases, insecticide and fungicide applications were carried out according to the severity of the attack, defining the product according to the identified disease, in constant observations throughout the crop cycle.

Sowing was carried out in 2012, on May 25 and in 2013, on July 10 . The basic fertilization used was $200 \mathrm{~kg} \mathrm{ha}^{-1}$ of the formulation NPK (08-24-12). In coverage, $115 \mathrm{~kg} \mathrm{ha}^{-1}$ of nitrogen were applied for all managements. The average plant population established was 310 plants $\mathrm{m}^{-2}$.

Traits available. Mass of a thousand grains - MMG: measured by manual counting of eight repetitions of 100 grains, expanding to a mass of one thousand grains in grams (g) (Brasil 2009). Number of Grains per Spike - NGE: made by counting the number of grains present in the main spike, results in units. Grain Mass on Main Spike MGEP: carried out through the total weighing of grains obtained from each plant, results expressed in g. Grain yield - RG: determined by average grain mass per plant and corrected for sowing density, results in kilograms per hectare $\left(\mathrm{kg} \mathrm{ha}^{-1}\right)$. Plant height - EPL: determined by measuring the base of the spike to its upper, results expressed in centimeters $(\mathrm{cm})$. Number tillers fertile - NAF: performed four weeks after anthesis of the spikes, computing the number of tillers with spike present, results expressed in units. Spike length - CESP: carried out using the spike base until a higher fall, results expressed in $\mathrm{cm}$.

Statistical analysis. The data obtained were submitted to the diagnosis of univariate normality of the residues using the Shapiro-Wilk test (Shapiro and Wilk 1965). Subsequently, a joint analysis was carried out to identify the presence of interaction between genotype $\times$ agricultural crop $\times$ source of $\mathrm{N} \times$ management of $\mathrm{N}$ at $5 \%$ probability. After realized Pearson's linear correlation with evidenced the linear trend associations between characters (Carvalho et al. 2004). The simple correlation analysis aims to identify the linear trend between the characters, expressed by coefficients that comprise magnitudes between 0 and 1, in the sense of a positive or negative sign. These coefficients are classified as null $(r=0.00)$, low or weak $(r=0.00$ to $r=0.29)$, intermediate or medium $(r=$ 0.30 to $r=0.59)$; high or strong $(r=0.60$ to $r=1.00)$ according to the classification of Carvalho et al. (2004).

Pearson's correlation coefficients are identical to the phenotypic correlation coefficients. The calculation of the correlation coefficients was performed as described by Steel and Torrie (1980) using the equation:

$\mathrm{r}_{\mathrm{P}(\mathrm{xy})}=\frac{\operatorname{COV}_{\mathrm{P}(\mathrm{XY})}}{\sqrt{\sigma_{\mathrm{P}(\mathrm{X})^{*}} \sigma_{\mathrm{P}(\mathrm{Y})}}}$

where, $\operatorname{COV}_{\mathrm{P}(\mathrm{XY})}=$ phenotypic covariance between the characters $\mathrm{X}$ and $\mathrm{Y} ;{ }_{\mathrm{P}(\mathrm{X})} ; \sigma_{\mathrm{P}(\mathrm{Y})}=$ standard deviation of characters $\mathrm{X}$ and $\mathrm{Y}$. 
The hypothesis was tested at the $95 \%$ level of significance by the $t$ test described by Steel and Torrie (1980).

$\mathrm{t}=\frac{\mathrm{r}}{\sqrt{1-\mathrm{r}^{2}}} \sqrt{\mathrm{n}-2}$

where, $r=$ correlation coefficient between the characters $X$ and $Y ; n=$ degree of freedom.

The phenotypic correlation coefficients were divided into direct and indirect effects of the wheat yield components (variables independent of the regression model) on grain yield (dependent variable) through the trail analysis (Wright 1921).

The calculation of the direct and indirect effects of path analysis was performed as described by Cruz and Carneiro (2006) using the model:

$\mathrm{Y}=\beta_{1} \mathrm{X}_{1}+\beta_{2} \mathrm{X}_{2}+\ldots+\beta_{\mathrm{n}} \mathrm{X}_{\mathrm{n}}+\varepsilon$

where, $X_{1}, X_{2}, \ldots X_{n}$ there are explanatory variables, $\beta_{n}$ are the angular coefficient equation of path and $Y$ the variable-base (or dependent variable).

So, in a general way, the coefficient of path was estimate, based in the systems of equations $X^{\prime} X \beta=X^{\prime} Y(L i$ 1975), being:

$\mathrm{X}^{\prime} \mathrm{Y}=\left(\begin{array}{c}\mathrm{r}_{1 \mathrm{y}} \\ \mathrm{r}_{2 \mathrm{y}} \\ \vdots \\ \mathrm{r}_{\mathrm{ny}}\end{array}\right), \mathrm{X}^{\prime} \mathrm{Y}=\left(\begin{array}{cccc}1 & \mathrm{r}_{12} & \ldots & \mathrm{r}_{1 \mathrm{n}} \\ \mathrm{r}_{12} & 1 & \ldots & \mathrm{r}_{2 \mathrm{n}} \\ \vdots & \vdots & \ddots & \vdots \\ \mathrm{r}_{1 \mathrm{n}} & \mathrm{r}_{2 \mathrm{n}} & \ldots & 1\end{array}\right) \mathrm{e} \beta=\left(\begin{array}{c} \\ \mathrm{p}_{1} \\ \mathrm{p}_{2} \\ \vdots \\ \mathrm{p}_{\mathrm{n}}\end{array}\right)$

Thus, performing the decomposition of the correlation between the dependent variable and the explanatory variables as follows (Cruz and Carneiro 2006):

$\mathrm{r}_{1 \mathrm{y}}=\mathrm{p}_{1}+\mathrm{p}_{2} \mathrm{r}_{12}+\ldots+\mathrm{p}_{\mathrm{n}} \mathrm{r}_{1 \mathrm{n}}$

$\mathrm{r}_{2 y}=\mathrm{p}_{1} \mathrm{r}_{12}+\mathrm{p}_{2}+\ldots+\mathrm{p}_{\mathrm{n}} \mathrm{r}_{2 \mathrm{n}}$

,... $\quad \cdots$

$\mathrm{r}_{\mathrm{ny}}=\mathrm{p}_{1} \mathrm{r}_{\mathrm{ln}}+\mathrm{p}_{\mathrm{n} 2}+\ldots+\mathrm{p}_{\mathrm{n}}$

$r_{i y}=p_{i}+\sum_{j \neq i}^{n} p_{j} r_{i j}$

where, riy: correlation between the main variable selected by the researcher $(y)$ and the i-th explanatory variable; pi: measure of the direct effect of variable $i$ on the main variable; pirij: measure of the indirect effect of variable $i$, via variable $\mathrm{j}$, on the main variable.

The coefficient of determination path diagram is given by:

$\mathrm{R}^{2}=\mathrm{p}_{1} \mathrm{r}_{1 y}+\mathrm{p}_{2} \mathrm{r}_{2 y}+\ldots+\mathrm{p}_{\mathrm{n}} \mathrm{r}_{\mathrm{ny}}$

The residual effect is estimated through:

$P_{\varepsilon}=\sqrt{1-R^{2}}$

The degree of multicollinearity of the matrix $X ' X$ was established based on the condition number (NC). It was classified as low $(N C<100)$, moderate to strong $(100<N C<1000)$ and severe $(N C>1000)$ (Montgomery and Peck 1982). The analyzes were performed using the computer program Genes (Cruz 2013) and using the Statistical Analysis System (SAS 2013).

\section{RESULTS AND DISCUSSION}

Analysis of variance - ANOVA. Joint analysis of variance revealed significance $(p<0.05)$ for the interaction genotype $\times$ crop $\times N$ management only for the character MGEP, there was interaction between crop $\times$ genotype for MGEP, NAF and CESP. Between agricultural crop $\times \mathrm{N}$ source there was interaction for the character NAF. For the genotype effect, there was a significant effect for the characters MMG, MGEP, EPL, NAF and CESP. For the effect of the agricultural harvest there was a significant effect for the characters MMG, NGE, MGEP, RG, EPL and NAF. For the nitrogen management effect, significant effects were observed in the variables NGE, MGEP, RG, EPL and CESP (Table 1).

Estimated coefficients of variation were satisfactory for the characters measured in the experiment according to the classification of Pimentel Gomes (2009), revealing a good level of precision in the field experiment, except for 
the NAF character. The selection of genotypes in the field is carried out based on the phenotype (Baretta et al. 2016). As a result, in this research we chose to estimate phenotypic correlations and their consequences in direct and indirect effects.

Table 1. Summary variance analysis for seven yield components in wheat to two harvests, three genotypes, two sources, and four nitrogen management

\begin{tabular}{|c|c|c|c|c|c|c|c|c|}
\hline \multirow{2}{*}{ SV } & \multicolumn{8}{|c|}{ Mean square } \\
\hline & DF & MMG & NGE & MGEP & $\mathrm{RG}$ & EPL & NAF & CESP \\
\hline Block & 2 & 6.36 & 144.32 & 2.26 & 5.32 & 23.29 & 0.30 & 0.26 \\
\hline Genotype (G) & 2 & $61.45^{*}$ & $2,739.12$ & $6.59^{*}$ & 26.89 & $321.21^{*}$ & $2.17^{\star}$ & $6.56^{*}$ \\
\hline Residue A & 4 & 0.65 & $1,330.86$ & 1.21 & 9.39 & 12.19 & 0.10 & 0.03 \\
\hline Plot & 8 & 17.28 & $1,386.29$ & 2.82 & 19.93 & 92.22 & 0.67 & 2.47 \\
\hline Year $(Y)$ & 1 & $95.5^{\star}$ & $28,683.32^{*}$ & $177.71^{*}$ & $59.87^{\star}$ & $1,208.95^{\star}$ & $3.99^{*}$ & 0.75 \\
\hline$Y^{*} G$ & 2 & 1.53 & 787.31 & $5.82^{*}$ & 3.07 & 14.4 & $0.53^{*}$ & $3.44^{*}$ \\
\hline Source (Management - S) & 7 & 3.17 & $3,940.09^{*}$ & $4.75^{\star}$ & $46.74^{\star}$ & $40.56^{*}$ & $0.35^{\star}$ & $1.61^{*}$ \\
\hline$Y^{*} S$ & 7 & 0.81 & 914.56 & 0.82 & 13.47 & 15.26 & $0.34^{*}$ & 0.23 \\
\hline $\mathrm{G}^{*} \mathrm{~S}$ & 14 & 1.25 & 467.57 & 1.31 & 9.74 & 10.57 & 0.14 & 0.15 \\
\hline$Y^{*} G^{*} S$ & 14 & 0.95 & $1,331.69$ & $2.77^{\star}$ & 10.93 & 13.68 & 0.18 & 0.03 \\
\hline Residue B & 90 & 1.51 & $1,029.58$ & 1.1 & 9.34 & 9.5 & 0.14 & 0.21 \\
\hline VC (\%) & & 3.89 & 10.56 & 10.16 & 20.24 & 3.46 & 47.69 & 5.91 \\
\hline
\end{tabular}

Analysis of linear correlation. Pearson's linear correlation was performed individually for each of the four nitrogen managements. Linear associations were made for the seven characters, being: MMG, NGE, MGEP, RG, EPL, NAF and CESP, therefore, 21 associations were obtained for each nitrogen management, of these only eight were significant for management I and III, nine for management II and five for management IV at $5 \%$ probability.

The mass of a thousand grains (MMG) showed a strong and positive correlation with MGEP $(r=0.60)$ and an intermediate and positive correlation with CESP $(r=0.36)$ when $\mathrm{N}$ was not applied in coverage (Management $\mathrm{I}$ ) (Figure 1 - I). A similar result was observed when management III was used (Figure 2 - II), indicating that the increase in the length of the ear and the mass of grains in the main ear tends to increase the mass of a thousand grains. The main spike comes from the main stem, which is the first reproductive structure to be emitted in relation to the tillers, which arise from the vegetative stage V3 - V4. This time difference may reflect a greater targeting of the photoassimilates produced to the main ear of the plant, characterized as the main drain and justifying the largest mass of wheat grain. According to McMaster (1997), the nitrogen available during the grain filling period, favors the maintenance of the active leaf area for longer and contributes to the production of photoassimilates, reflecting in heavier grains (Ayoub et al. 1994).

When using nitrogen management II, III and IV, intermediate and negative correlations were observed between NAF and MMG, with magnitudes of $r=-0.36, r=-0.52$ and $r=-0.40$, respectively (Figure $1-\mathrm{II}$ and Figure $2-\mathrm{I}$ and II. This behavior reveals that the smallest number of tillers with viable ears tends to increase the mass of a thousand grains. Carvalho et al. (2015), studying the associations between the morphological characters and yield components in dual purpose wheat under different cuts, observed a negative correlation between the number of fertile tillers and the mass of a thousand grains when the wheat was not subjected to any cut. Wheat tillering capacity has a compensatory ability during the plant's phenological cycle, due to its high relationship with the number of ears per plant, while self-sufficient and photosynthetically active tillers tend to increase grain productivity (Fioreze and Rodrigues 2012). When using nitrogen fully in the tiller (management II), there is an intermediate and negative association between MMG and EPL $(r=-0.36)$, where the smaller plant height tends to increase the unit mass of the grain.

Number of grains per spike (NGE) showed a strong and positive correlation with MGEP $(r=0.71)$, and RG $(r=$ $0.64)$ and intermediate and positive with CESP $(r=0.51)$ for management $\mathrm{I}$, indicating that the increase in the length of the ear tends to increase the number of grains in the ear, resulting in a greater mass of grains in the main ear and, consequently, higher grain yield. Similarly, in the management of nitrogen III, strong and positive correlations were observed between NGE and MGEP $(r=0.71)$ and RG $(r=0.64)$. However, when using management II and IV, a correlation was observed only with MGEP, $r=0.80$ and $r=0.43$, respectively. Gondim et al. (2008), studying the associations between yield components, plant characters and the grain yield of wheat genotypes, found that the number of grains per ear and the mass of a thousand grains are the main components of 
yield when wheat is submitted to defoliation. Similar results were found by studies by Caierão et al. (2001), Vieira et al. (2007) and Vesohoski et al. (2011).

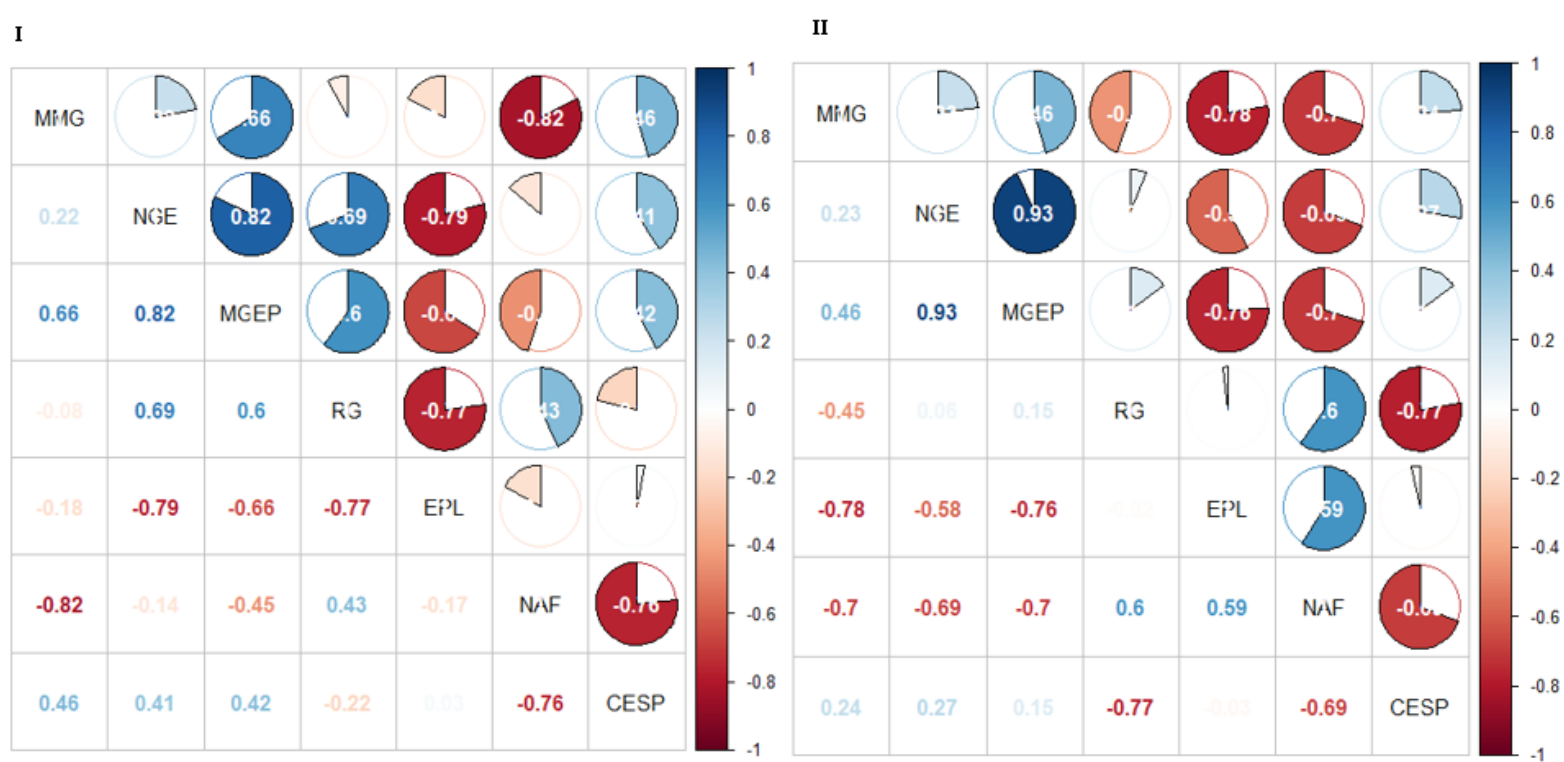

Figure 1. Pearson's correlation linear estimate for seven yield components of wheat in the two harvest, three genotypes and two sources nitrogen.

† MMG - Mass of a thousand grains; NGE - Number of grains per spike; MGEP - Main grain mass on the spike; RG - grain yield; EPL - Plant height; NAF - Number of fertile tillers and CESP - Spike length;

I: Nitrogen management I and II: nitrogen management II

III

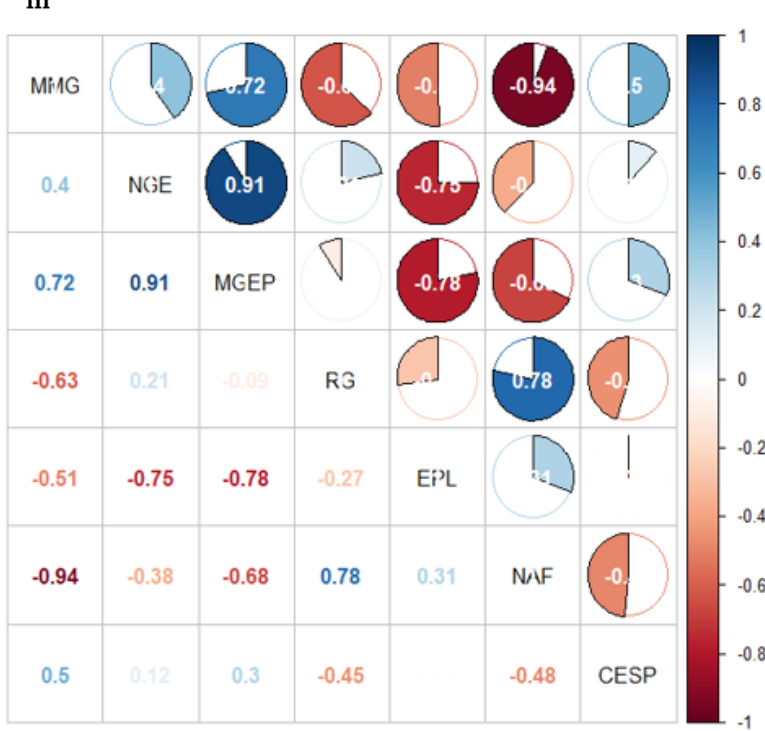

IV

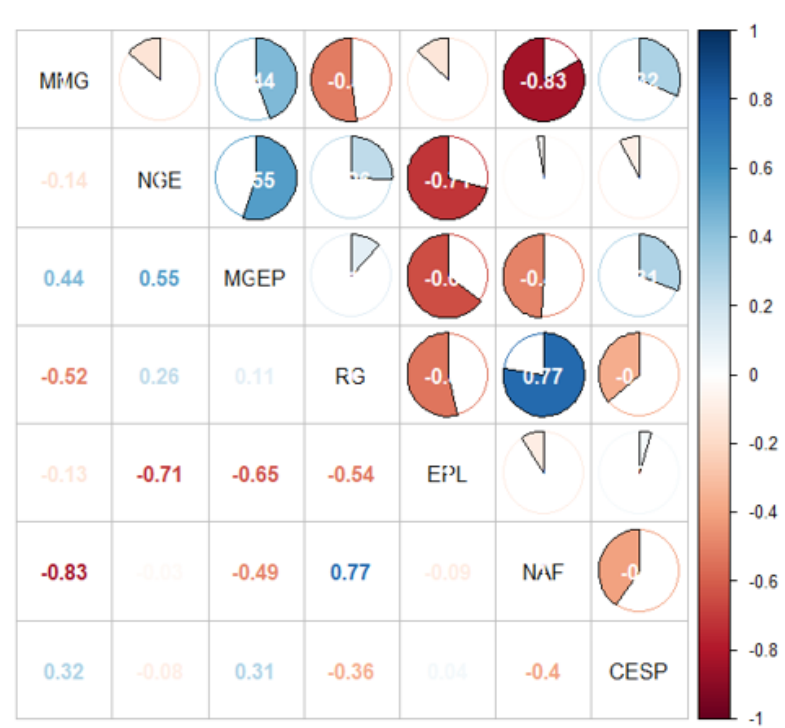

Figure 2. Pearson's correlation linear estimate for seven yield components of wheat in the two harvest, three genotypes and two sources nitrogen.

† MMG - mass of a thousand grains; NGE - number of grains per spike; MGEP - main grain mass on the spike; RG - grain yield; EPL - plant height; NAF - number of fertile tillers and CESP - spike length. III: nitrogen management III and IV: management IV

The number of grains per spike is a component affected by the number of spikelets produced and the number of grains per spike (Langer and Hanif 1973). According to Rodrigues et al. (2011), the potential number of ear spikelets is defined in the tapering period, more precisely between the phase described as "double ring", characterized as the beginning of the reproductive node differentiation and the "terminal spike", when the last spike and the stem begins to elongate. At this stage, floral differentiation occurs, where the environment is a factor that can strongly influence the number of flowers that differ by spikelet (Rodrigues 2000). Thus, it can be highlighted that nitrogen management can affect the availability of nitrogen during this period, which may alter the contribution of wheat grain yield components. 
The grain mass of the main spike (MGEP) revealed, for nitrogen management I, III and IV, positive correlations with the RG ( $r=0.73, r=0.46$ and $r=0.33$, respectively) and the CESP ( $r=0.43, r=0.38$ and $r=0.36$, respectively). Thus, the increase in the length of the spike and the mass of grains in the main spike tends to increase the yield of wheat grains. Silva (2009) considers that the spike length is a trait of interest for genetic improvement, as it is closely related to the components that define grain yield in wheat culture.

The number of fertile tillers (NAF) showed, for nitrogen management I, II, III and IV an intermediate to strong and positive correlation with grain yield $(r=0.54, r=0.57, r=0.74$ and $r=0.67$, respectively). Thus, it can be inferred that regardless of the nitrogen management used, the largest number of fertile tillers in the wheat plant tends to increase grain yield. These results corroborate those found by Kavalco et al. (2014), who, when studying the phenotypic, genetic and environmental correlations of agronomic variables under grain production in two cultivation environments, observed a high correlation between the number of fertile tillers and grain production, indicating that this character can be used as an indirect selection criterion for wheat grain production.

Plant height (EPL) showed an intermediate and positive correlation with NAF ( $r=0.37)$ for management II, indicating that when nitrogen is applied to the tiller, taller plants tend to increase the number of tillers with the presence of fertile spike. There were no significant correlations between these characters for the other nitrogen management used.

Path analysis. The matrix of the phenotypic linear correlation coefficients, for each nitrogen management, was submitted to the diagnosis of multicollinearity, where the number of conditions of the matrix (NC) was tested, in order to reveal which of the characters were additive to the model. The diagnosis revealed weak collinearity in managements I, II, II and IV, with NC of 16.32, 17.64, 18.58 and 4.59 , respectively.

Phenotypic associations of cause and effect were used for the two cultivation environments, three genotypes and two nitrogen sources individually for each of the four nitrogen managements (Tables 2 and 3), where the grain yield was fixed as a character dependent and the characters MMG, NGE, MGEP, EPL, NAF and CESP were considered as explanatory.

Table 2. Estimates of direct and indirect phenotypic effects in six characters of agronomic interest on grain yield in two years of cultivation, three genotypes, and two nitrogen sources.

\begin{tabular}{|c|c|c|c|c|c|c|}
\hline \multicolumn{7}{|l|}{ Management I } \\
\hline & MMG & NGE & MGEP & EPL & NAF & CESP \\
\hline Direct on RG & -0.07 & -0.04 & 0.07 & 0.02 & 0.62 & 0.07 \\
\hline Ind. via MMG & - & -0.02 & -0.03 & -0.01 & 0.02 & -0.03 \\
\hline Ind. via NGE & -0.01 & - & -0.02 & -0.01 & -0.01 & -0.03 \\
\hline Ind. via MGEP & 0.51 & 0.59 & - & -0.05 & -0.08 & 0.35 \\
\hline Ind. via EPL & -0.01 & -0.01 & 0.36 & - & 0.01 & 0.01 \\
\hline Ind. via NAF & -0.18 & 0.08 & 0.01 & 0.04 & - & -0.12 \\
\hline Ind. via CESP & 0.03 & 0.04 & -0.11 & 0.02 & -0.01 & - \\
\hline Total & 0.27 & 0.64 & 0.26 & 0.02 & 0.54 & 0.26 \\
\hline Determination coefficient & 0.91 & & & & & \\
\hline Effect of the residual variable & 0.29 & & & & & \\
\hline Matrix determinant & 0.11 & & & & & \\
\hline \multicolumn{7}{|l|}{ Management II } \\
\hline & MMG & NGE & MGEP & EPL & NAF & CESP \\
\hline Direct on RG & -0.20 & -0.35 & 1.00 & -0.05 & 0.83 & -0.03 \\
\hline Ind. via MMG & - & -0.01 & -0.06 & 0.07 & 0.06 & -0.03 \\
\hline Ind. via NGE & -0.01 & - & -0.28 & 0.05 & 0.11 & -0.09 \\
\hline Ind. via MGEP & 0.36 & 0.90 & - & -0.28 & -0.44 & 0.19 \\
\hline Ind. via EPL & 0.02 & 0.01 & 0.01 & - & -0.01 & -0.01 \\
\hline Ind. via NAF & -0.27 & -0.27 & -0.32 & 0.31 & - & -0.27 \\
\hline Ind. via CESP & -0.01 & -0.01 & -0.01 & -0.01 & 0.01 & - \\
\hline Total & -0.11 & 0.27 & 0.46 & 0.09 & 0.57 & -0.23 \\
\hline Determination coefficient & 0.92 & & & & & \\
\hline Effect of the residual variable & 0.27 & & & & & \\
\hline Matrix determinant & 0.12 & & & & & \\
\hline
\end{tabular}

${ }^{\dagger}$ MMG - Mass of a thousand grains; NGE - Number of grains per spike; MGEP - Main grain mass on the spike; RG - grain yield; EPL - Plant height; NAF - Number of fertile tillers and CESP - Spike length. 
Table 3. Estimates of direct and indirect phenotypic effects in six characters of agronomic interest on grain yield in two years of cultivation, three genotypes, and two nitrogen sources.

\begin{tabular}{|c|c|c|c|c|c|c|}
\hline \multicolumn{7}{|l|}{ Management III } \\
\hline & MMG & NGE & MGEP & EPL & NAF & CESP \\
\hline Direct on RG & 0.19 & 0.09 & 0.43 & -0.06 & 0.97 & -0.09 \\
\hline Ind. via MMG & - & 0.05 & 0.10 & -0.02 & -0.1 & 0.07 \\
\hline Ind. via NGE & 0.02 & - & 0.07 & -0.01 & 0.01 & 0.02 \\
\hline Ind. via MGEP & 0.23 & 0.35 & - & -0.09 & -0.11 & 0.16 \\
\hline Ind. via EPL & 0.01 & 0.01 & 0.01 & - & -0.01 & -0.02 \\
\hline Ind. via NAF & -0.50 & 0.01 & -0.25 & 0.22 & - & 0.04 \\
\hline Ind. via CESP & -0.03 & -0.02 & -0.03 & -0.02 & -0.01 & - \\
\hline Total & -0.09 & 0.47 & 0.33 & 0.01 & 0.74 & 0.20 \\
\hline Determination coefficient & 0.87 & & & & & \\
\hline Effect of the residual variable & 0.36 & & & & & \\
\hline Matrix determinant & 0.09 & & & & & \\
\hline \multicolumn{7}{|l|}{ Management IV } \\
\hline & MMG & NGE & MGEP & EPL & NAF & CESP \\
\hline Direct on RG & 0.16 & -0.02 & 0.56 & -0.01 & 0.85 & -0.14 \\
\hline Ind. via MMG & - & -0.01 & 0.05 & -0.01 & -0.06 & 0.04 \\
\hline Ind. via NGE & 0.01 & - & -0.01 & 0.01 & -0.01 & 0.20 \\
\hline Ind. via MGEP & 0.19 & 0.24 & - & -0.11 & -0.11 & 0.20 \\
\hline Ind. via EPL & 0.01 & 0.01 & 0.01 & - & -0.01 & -0.01 \\
\hline Ind. via NAF & -0.34 & 0.06 & -0.17 & 0.02 & - & 0.01 \\
\hline Ind. via CESP & -0.03 & -0.01 & -0.51 & -0.02 & -0.01 & - \\
\hline Total & -0.03 & 0.26 & 0.38 & -0.12 & 0.67 & 0.11 \\
\hline Determination coefficient & 0.77 & & & & & \\
\hline Effect of the residual variable & 0.48 & & & & & \\
\hline Matrix determinant & 0.41 & & & & & \\
\hline
\end{tabular}

Increasing grain yield is one of the main objectives of wheat breeding programs, however, this is not an easy task, due to the fact that grain yield is a character expressed by the action of a large number of genes (Allard 1971), being strongly influenced by the environment and therefore with low heritability. In this sense, a valid alternative is the use of indirect selection to select genotypes with higher grain yield, and to understand which characters should be considered to guide the selection strategy through characters of easy measurement, high heritability and great effect on the character of interest (Hartwig et al. 2007).

The knowledge of the interrelationships between characters that are part of the yield components is of fundamental importance, since the yield of wheat grains can be attributed to the product of three main components, namely, number of spike per unit of area, number of grains per spike and average grain mass, and their behavior varies, to a certain extent, independently of each other (Gondim et al. 2008).

Table 2 shows the estimates of the direct and indirect effects of the explanatory characters on the RG for the management of $\mathrm{N} \mathrm{I}$ and II.

Regarding nitrogen management I, NGE showed a strong and positive linear correlation with the $R G(r=0.64)$, due to the indirect effects presented by MGEP (0.59). In a study by Carvalho et al. (2015), a positive correlation was reported between the number of grains and the grain mass of the spike of wheat, assuming that the greater number of grains per spike increases the grain mass in the main spike.

In the Table 3 are demonstrated estimating direct and indirect effects explanatory characters about RG for the management III and IV. NAF revealed a high and positive direct effect on RG, corroborating the linear coefficient in sense and magnitude, making it possible to establish as true the hypothesis of linear association between these characters. Thus, it appears that the increase in the number of fertile tillers tends to increase the grain yield of wheat. These results corroborate with Vieira et al. (2007), who studied the genetic correlations between the primary and secondary components on wheat grain yield, concluded that the number of tillers per linear meter and the number of grains per spikelet are the primary characters that are most important in determining yield.

Regarding nitrogen management II, it is observed that MGEP had a high and positive effect on RG, under negative indirect effect of NGE and NAF, showing a positive total correlation $(r=0.46)$. 
When using nitrogen management III, it was observed that the NGE presents an intermediate and positive linear correlation with the $R G(r=0.47)$, however this behavior is associated with the positive indirect effects revealed by MGEP (0.35). MGEP revealed a positive linear correlation with $R G(r=0.33)$, where the direct effect was positive (0.43), highlighting the negative contribution of the indirect effect via NAF $(-0.25)$. This behavior may be related to the greater number of fertile tillers not being effectively linked to greater production of grains in these structures, resulting in competition for photoassimilates and consequent reduction in the grain mass of the main spike.

Nitrogen has a stimulating function in axillary buds, in which early applications of this nutrient may reflect a higher emission of tillers. Thus, depending on the genotype tapering potential, applications can be given more early in the plant's development, or later, in order to increase the number of fertile tillers per plant. However, when there is $\mathrm{N}$ deficiency in the wheat tillering phase, asynchrony occurs in the emission of tillers, in which they have less chance of surviving, even if the plant receives supplementation in earlier development stages (Mundstock 1999).

The presence of tillers can affect wheat productivity in a positive or negative way, depending on the availability of environmental resources, such as water, light and nutrients (Elhani et al. 2007). In cereals, the relationship between the main stem and the tillers affects the number of fertile tillers and this relationship is dependent on the conditions of the environment during the initiation of the tiller's primordium and in the subsequent stages of development (Almeida and Mundstock 2001). When using nitrogen management IV, a direct intermediate and positive effect was observed between MGEP $(0.56)$ and the contribution of negative indirect effects via NAF $(-0.17)$ and CESP (-0.51), justifying the linear correlation positive between MGEP and RG $(r=0.38)$.

NAF showed a positive correlation with the RG, with a high direct and positive effect and influenced by the negative indirect effect via MGEP, when using nitrogen managements II, III and IV, noting that there was a similar behavior of the cause and effect associations due to these nitrogen managements used, where the sense of the associations was maintained, only modifying their magnitudes. Thus, the selection of genotypes via the number of fertile tillers, combined with the lower mass of grains in the main ear and the larger number of grains per spike tends to increase the gains in grain yield. The survival of the tillers is conditioned to the balance presented between the development of the main stem and the tillers, therefore, in order to become productive, the tillers must show growth rates similar to the main stem, thus being able to contribute to the final grain production (Wobeto 1994).

Determination coefficients were high for management I $\left(R^{2}=0.91\right)$, II $\left(R^{2}=0.91\right)$, III $\left(R^{2}=0.87\right)$ and IV $\left(R^{2}=\right.$ 0.77), thus accepting the variations in the dependent variable are explained by the variations in the explanatory variables. Consequently, the results obtained in the present study were adequately explained by the proposed model.

In conclusion, top dressing nitrogen management modifies the magnitude of the associations between RG and its components in wheat. The number of fertile tillers regardless of top-dressing management has a positive cause and effect relationship with grain yield in wheat. The grain mass of the main spike in management II, management III and management IV demonstrates a positive cause and effect relationship with grain yield in wheat.

\section{Acknowledgements}

The authors are grateful to CNPq, CAPES, FAPERGS for financial and grants aid.

\section{References}

Ayoub M et al. 1994. Timing and level of nitrogen fertility effects on spring wheat yield in Eastem Canada. Crop Science 34:748-756.

Allard RW. 1971. Princípios do melhoramento genético das plantas. São Paulo: Edgard Blücher Ltda. 485p.

Almeida ML, Mundstock CM. 2001. A qualidade da luz afeta o afilhamento em plantas de trigo, quando cultivadas sob competição. Ciência Rural 31:401-408.

Alvares CA et al. 2013. Köppen's climate classifcation map for brazil. Meteorologische Zeitschrift 22:711-728.

Baretta D et al. 2016. Path analysis for morphological characters and grain yield of maize hybrids. Australian Journal of Crop Science 10:16551661.

Barraclough PB et al. 2010. Nitrogen efficiency of wheat: Genotypic and environmental variation and prospects for improvement. European Journal of Agronomy 33:1-11.

Benin $\mathrm{G}$ et al. 2012. Agronomic performance of wheat cultivars in response to nitrogen fertilization levels. Acta Scientiarum Agronomy 34:275283.

Caierão E et al. 2001. Seleção indireta em aveia para o incremento no rendimento de grãos. Ciência Rural 31:231-236.

Brasil. 2009. Ministério da Agricultura, Pecuária e Abastecimento. Regras para análise de sementes. Brasília: Mapa/ACS, 395 p.

Carvalho FIF et al. 2004. Estimativas e implicações da correlação no melhoramento vegetal. Pelotas: UFPel. 142p.

Carvalho IR et al. 2015. Correlações canônicas entre caracteres morfológicos e componentes de produção em trigo de duplo propósito. Pesquisa Agropecuária Brasileira 50:690-697.

Conab - Companhia Nacional de Abastecimento. 2019. Acompanhamento da Safra Brasileira: Safra 2019 de trigo. Disponível em: <http://www.conab.gov.br/OlalaCMS/uploads/arquivos/17_05_11_14_23_14_boletim_graos_maio_2019.pdf>.Acesso em: 5 mai. 2019. 
Cruz CD 2013. GENES - a software package for analysis in experimental statistics and quantitative genetics. Acta Scientiarum Agronomy 35 : 271-276.

Cruz CD et al. 2014. Modelos biométricos aplicados ao melhoramento genético. 2: 3ed. Viçosa: Editora UFV, $668 \mathrm{p}$.

Cruz CD, Carneiro PCS. 2006. Modelos Biométricos aplicados ao melhoramento genético. 2ed. Viçosa: UFV, $586 \mathrm{p}$.

Cruz CD, Regazzi AJ. 1997. Modelos biométricos aplicados ao melhoramento genético. Viçosa: UFV 389 p.

Elhani $S$ et al 2007. Contribution of main stem and tillers to durum wheat (Triticum turgidum L. var. durum) grain yield and its components grown in Mediterranean environments. Field Crops Research 103:25-35.

Fioreze SL, Rodrigues JD. 2012. Perfilhamento do trigo em função da aplicação de regulador vegetal. Revista Brasileira de Ciências Agrárias 7:750-755.

Gondim T et al. 2008. Análise de trilha para componentes do rendimento e caracteres agronômicos de trigo sob desfolha. Pesquisa Agropecuária Brasileira 43:487-493.

Górny AG et al. 2011. Inheritance of the efficiency of nitrogen uptake and utilization in winter wheat (Triticum aestivum L.) under diverse nutrition levels. Euphytica 177: 191-206.

Hartwig I et al. 2007. Estimativa de coeficientes de correlação e trilha em gerações segregantes de trigo hexaplóide. Bragantia 66:203-218.

Kavalco SAF et al. 2014. Análise de trilha em genótipos de trigo submetidos ao estresse por encharcamento. Semina: Ciências Agrárias 35:1683-1696.

Kutman UB et al. 2011. Improved nitrogen status enhances zinc and iron concentrations both in the whole grain and the endosperm fraction of wheat. Journal of Cereal Science 53:118-125.

Langer RHM, Hanif M. 1973. A study of floret development in wheat (Triticum aestivum). Annals of Botany 37:743-751.

Li CC. 1975. Path analysis - a primer. 3. ed. Pacific Grove, Boxwood. 347 p.

McMaster GS. 1997. Phenology, development and growth af the wheat (Triticum aestivum) shoot apex: a review. Advances in Agronomy 59: 63-118.

Montgomery DC, Peck EA. 1982. Introduction to linear regression analysis. John Willey and Sons, New York. 504 p.

Mundstock CM. 1999. Planejamento e manejo integrado da lavoura de trigo. Porto Alegre: Evnagraf. 227 p.

Paterniani E, Campos MS. 2005. Melhoramento do milho. In: Borém, A. (Ed.). Melhoramento de espécies cultivadas. 2. ed. Viçosa, MG: Editora UFV. $969 \mathrm{p}$.

Pimentel-Gomes F. 2009. Curso de estatística experimental. 15.ed. Piracicaba: Esalq. 451 p.

Pinnow $C$ et al. 2013. Qualidade industrial do trigo em resposta à adubação verde e doses de nitrogênio. Bragantia 72:20-28.

Rodrigues O. 2000. Manejo de trigo: bases ecofisiológicas. In: Cunha, G. R da; Bacltchuk, B. (Org.). Tecnologias para produzir trigo no Rio Grande do Sul. Porto Alegre: Assembléia Legislativa do Rio Grande do Sul - Comissão de Agricultura, Pecuária e Cooperativismo; Passo Fundo: Embrapa Trigo. pp.120-155.

Rodrigues $\mathrm{O}$ et al. 2011. Ecofisiologia de trigo: bases para o elevado rendimento de grãos. In: Pires JLF, Vargas L, Cunha GR (Ed.). Trigo no Brasil: Bases para a produção competitiva e sustentável. Passo Fundo: Embrapa Trigo. pp.115-134.

Santos HG et al. 2006 Sistema brasileiro de classificação de solos. Rio de Janeiro: Embrapa Solos. 306 p.

SAS 2013. GETTING Started with the SAS ${ }^{\circledR}$ Learning Edition. Cary, NC: SAS Institute. 81p.

Shapiro SS, Wilk MB. 1965. An Analysis of Variance Test for Normality (Complete Samples). Biometrika 52:591-611.

Silva AH. 2009. Avaliação de genótipos de trigo duro quanto à produção de grãos e outros caracteres agronômicos no Estado de São Paulo. Dissertação (Mestrado), Instituto Agronômico de Campinas.

Silva AS et al. 2005. Análise de trilha para os componentes de rendimento de grãos em trigo. Bragantia 4:191-196.

Steel R, Torrie J. 1980. Principles and procedures of statistics a biometrical approach. 2nd ed., McGraw Hill. 633p.

Vesohoski $F$ et al. 2011. Componentes do rendimento de grãos em trigo e seus efeitos diretos e indiretos na produtividade. Revista Ceres 58:337-341.

Vieira EA et al. 2007. Análise de trilha entre os componentes primários e secundários do rendimento de grãos em trigo. Revista Brasileira de Agrociência 13:169-174.

Wobeto C. 1994. Padrão de afilhamento, sobrevivência de afilhos e suas relações com o rendimento de grãos em trigo. Dissertação (Mestrado em fitotecnia), Faculdade de Agronomia, Universidade Federal do Rio Grande do Sul, Porto Alegre.

Wright S. 1921. Correlation and causation. Journal of Agricultural Research 20:557-585.

Xu G 2012. Plant Nitrogen Assimilation and Use Efficiency. Annual Review of Plant Biology 63: 153-82. 